\title{
Pengembangan wisata alam kandung menjadi kawasan wisata lokal yang berwawasan lingkungan
}

\section{The development of natural tourism into an environmentally friendly local tourism area}

\author{
Andri Wahyudi \\ Universitas Tulungagung, Jl. Ki Mangun Sarkoro Beji, Boyolangu, Kabupaten Tulungagung, Indonesia
}

\author{
andriwahyudi1964@gmail.com
}

\begin{abstract}
ABSTRAK
Wisata alam Kandung adalah daerah di kawasan perbatasan wilayah Tulungagung dan Blitar mempunyai ciri-ciri khas/keunikan yang natural serta ditunjang beberapa persyaratan dalam rangka pengembangan destinasi wisata utamanya di bidang wisata alam.

Pengembangan wisata ini bertujuan untuk melakukan pengelolaan wisata alam yang profesional, bermuatan lokal, berkesinambungan, ramah lingkungan serta dapat meningkatkan kesejahteraan masyarakat.

Ada beberapa kendala diantaranya seperti : kurang menunjangnya faktor-faktor pendukung lain (infrastruktur \& suprastruktur)seperti jalan, listrik, peran serta/warga masayarakat sekitar kawasan wisata alam menyangkut kesadaran terhadap lingkunganalam relatif rendah, keberfihakan pemerintah untuk menyebar-luasan informasi terkait dunia kepariwisataan kurang terintegrasi \& padu.
\end{abstract}

Kata kunci: Pengembangan Wisata, Alam Kandung, Kawasan Wisata Lokal, Berwawasan Lingkungan.

\begin{abstract}
Nature tourism Kandung is an area in the border area of Tulungagung and Blitar that has natural characteristics / uniqueness and is supported by several requirements in the framework of developing tourist destinations, especially in the field of natural tourism.

This tourism development aims to manage natural tourism that is professional, local, sustainable, environmentally friendly and can improve the welfare of the community.

There are several obstacles including: lack of support for other supporting factors (infrastructure \& superstructure) such as roads, electricity, participation / community members around natural tourism areas regarding awareness of the natural environment is relatively low, the government's partiality to disseminate information related to the world of tourism less integrated \& coherent.
\end{abstract}

Keywords: Tourism Development, Nature Kandung, Local Tourism Area, Environmental Friendly 


\section{PENDAHULUAN}

Dewasa ini kalau kita berbicara mengenai dunia kepariwisataan memang selalu menarik dan terasa sulit untuk mengakirinya, apakah hal tersebut asli/natural maupun hasil modifikasi/rekayasa dengan tema atau menggeluti bidang makanan khas/lokal, kesenian, pesisir, wisata-pertanian serta ada lagi bidang-bidang yang menarik.

Negara Indonesia mengalami progres kepariwisataan yang cukup pesat, dan bidang ini memberikan kontribusi signifikan terhadap peningkatan devisa.

Ini merupakan suatu bukti bahwa bisnis pariwisata apabila dikelola secara sungguhsungguh, baik dan profesional akan memberikan keuntungan yang menjanjikan (bagus) bagi pengelolanya serta sekaligus juga akan memberikan dampak/manfaat yang sangat baik/positip bagi masyarakat sekitar kawasan wisata.

Kemudian pengembangan suatu kawasana wisata secara langsung maupun tidak langsung dapat menjadikan magnet penggerak roda pergerakan ekonomi berupa terbukanya peluang usaha, munculnya lapangan kerja baru bagi masyarakat disekitar kawasan wisata.

Disamping itu kawasan wisata yang dipandang memiliki potensi untuk dikembangkan akan dilirik oleh pemerintah dalam hal penyediaan/pemberian kelengkapan sarana prasarana fasilitas penunjang perkembangan kawasan tersebut misalnya seperti perbaikan jalan dan lain lainnya.

Pemerintah Kabupaten Tulungagung di era otonomi daerah mengupayakan optimalisasi pada elemen manusia sebagai salah satu faktor produksi yang dimiliki untuk menjalankan program-program pengembangan kepariwisataan yang memiliki nilai tambah dan bermutu serta ramah lingkungan. Hal ini dilakukan dengan gencarnya menggarap beberapa destinasi wisata yang potensial salah satunya adalah Wisata Alam Kandung.

Dengan menggarap potensi alam yang ada/lokal secara sungguh-sungguh seperti pengembangan wisata alam Kandung bisa jadi hal ini juga terkait dengan konsep Ekowisata, yang menyatakan bahwa pengembangan wisata alam memiliki bagian yang tidak terpisahkan dengan masalah konservasi, kelestarian lingkungan alam, perbaikan ekonomi masyarakat sekitar kawasan wisata, perubahan kultur atau budaya (Fandeli, 2012).

Terjadinya perubahan trend kepariwisataan dunia dewasa ini, yakni wisatawan lebih banyak mengunjungi kawasan-kawasan wisata yang bernuansa alam dibanding yang lain. Hal tersebut bisa dimaknai sekaligus sebagai peluang serta merupakan cara dan jalan keluar agar terjadi pertambahan penghasilan serta taraf hidup rakyat menjadi meningkat. Selain itu pengembangan wisata alam rata-rata lebih bersifat padat karya \& jasa, menggerakkan perekonomian masyarakat lokal dengan tetap menjaga kelestarian alam itu sendiri

Wisata Alam Kandung mempunyai nilai tambah yang positip dan berpeluang untuk berkembangdengan dukungan beberapa persyaratan untuk pengembangan wisata alam di 
Kabupaten Tulungagung walaupun perlu pembenahan di bidang infrastruktur, partisipasi masayarakat, promosi, serta dukungan pemerintah.

Obyek Wisata Alam Kandung di wilayah tenggara Kabupaten Tulungagung memiliki daya tarik wisata untuk dikunjungi, terbukti adanya progres jumlah pengunjung dari waktu ke waktu semakin meningkat namun masyarakat masih menganggap Wisata Alam Kandung masih belum menjadi pilihan utama masyarakat sebagai tujuan wisata.

Karenanya diperlukan pengembangan Wisata Alam Kandung yang nantinya diharapkan ada pertumbuhan ekonomi/peningkatan pendapatan asli daerah Kabupaten Tulungagung secara umum, dengan jalan meningkatkan kesejahteraan masyarakat disekitar kawasan wisata alam Kandung dengan tetap menjaga kelestarian lingkungan alam.

Bertitik tolak dengan hal tersebut diatas maka peneliti ingin melihat seberapa besar potensi Wisata Alam Kandung kedepan bukan lagi sebagai pilihan alternatif melainkan sebagai tujuan utama pariwisata tidak hanya daerah Tulungagung dan sekitarnya tetapi Jawa Timur bahkan Indonesia dan tidak menutup kemungkinan juga sebagai tujuan wisata dunia.

Berdasarkan paparan yang telah disampaikan didepan maka permasalahan dalam penelitian ini yakni seberapa besar pengembangan Wisata Alam Kandung yang berwawasan lingkungan serta beberapa faktor yang mempengaruhi pengembangan Wisata.

Selanjutnya terkait dengan hal tersebut ingin diungkap bagaimanakah upaya pengembangan wisata Alam Kandung menjadi kawasan wisata lokal yang berkelestarian alam sekaligus diketemukan apa saja yang menjadi kendala pengembangan wisata Alam Kandung yang menjadi kawasan wisata lokal yang berwawasan lingkungan.

Disamping itu juga berupaya ingin mengetahui dan memahami pengembangan wisata Alam Kandung menjadi kawasan wisata lokal yang berwawasan lingkungan dan untuk mengetahui serta memahami faktor-faktor yang menjadi kendala pengembangan wisata Alam Kandung menjadi kawasan wisata lokal yang berwawasan lingkungan.

Kemudian yang juga tidak ketinggalan dengan penelitian ini berharap dan dimaksudkan sebagai bahan pertimbangan dalam hal ini Pemerintah Kabupaten Tulungagung, Dinas terkait dan stake-holder terkait upaya pengembangan kawasan pariwisata lokal berwawasan lingkungan di Kabupaten Tulungagung, sebagai tambahan khasanah \& pola pikir penulis kususnya di bidang perpariwisataan sekaligus juga untuk perbandingan bagi fihak-fihak yang memiliki ketertarikan yang sama tentang permasalahan, topik, tema penelitian sejenis.

\section{KERANGKA TEORI}

Secara etimologi kata Wisata berasal dari beberapa bahasa diantaranya : Tour (Inggris), Torah (Ibrani), Tornus (Latin) yang semuanya ada kesamaan makna yakni diartikan sebagai suatu 
upaya untuk membuat aktivitas melingkar atau dalam istilah lain disebut tour yang berarti mengelilingi sirkuit. Masyarakat awam seringkali menyamakan istilah wisata disama artikan dengan rekreasi, yang sebenarnya istilah paling mendasar dari wisata adalah sebuah perjalanan, sedangkan rekreasi tidak semuanya terkait dengan perjalanan. (Suyitno,2001).

Obyek \& daya tarik wisata dapat dinikmati melalui suatu kegiatan/perjalanan yang dilakukan secara bebas/sukarela dan hal tersebut tidak berlanglung secara permanen. Wisata memiliki karakteristik - karakteristik antara lain :

1. Tidak Permanen, wisatawan pulang ke daerah asal.

2. Berpengaruh terhadap sarana \& prsarana yang terkait dengan kawasan wisata alam, seperti : akses perhubungan, tempat penginapan, sarana/tempat untuk kuliner/makan, tempat pariwisata, sarana/layanan untuk oleh-oleh dan lain-lain.

3. Menstimuli/memunculkan keinginan masyarakat untuk melihat daerah wisata \& pertujukan wisata :

a. Mempunyai motivasi berbeda dengan maksud untuk mendapatkan kesenangan

b. Memungkinkan munculnya peluang dan kesempatan kerja baru bagi masyarakat sekitar kawasan wisata. (Suyitno, 2001).

Kegiatan Wisata \& Rekreasi dengan obyek alam baik yang (alami maupun modifikasi) akan memberikan kontribusi/keuntungan bagi wisatawan yang melakukan nya yakni berupa pemenuhan kebutuhan fisik \& psikis dengan tetap bersikap ramah terhadap lingkungan. (Anonymous, 1982 dalam Saragih, 1993).

Kegiatan rekreasi dan wisata alam adalah aktifitas yang menyasar pada obyek alam baik langsung ataupun tidak langsung akan dinikmati keindahan alam baik yang masih alami dan juga langkah-langkah modifikasi ke tempat tersebut.

Keseimbangan hidup manusia ingin diwujudkan dari hari-hari yang penuh dengan hiruk pikuk aktifitas dikota dengan Wisata alam yang alami, tenang bahkan sementara jauh dari kompleksitas pemenuhan kebutuhan hidup sehari-hari. Dengan demikian wisatawan yang berwisata secara otomatis kebugaran tubuhnya secara fisik/psikis akan kembali fres dan ini berpengaruh besar setelah mereka kembali pada unit kerja dan profesi sehari-hari.

Namun demikian yang perlu digarisbawahi bahwa upaya pengembangan kepariwisataan yang pada intinya sebagai pemenuhan kebutuhan manusia untuk memenuhi kebutuhan fisik dan psikisnya jangan sampai mengganggu kelestarian lingkungan alam.

Dengan kata lain kegiatan wisata yang dilakukan tetap menjaga daerah/kawasan berjalan secara alami dan tetap berkontribusi dalam kehidupan secara ekonomi, politik, serta berupaya mempertahankan sosial budaya masyarakat.

Ketentraman dan kebahagiaan hidup sebagai dambaan semua orang baik secara individu maupun kelompok dapat digapai untuk sementara melalui wisata alam. Karena untuk bisa mewujudkannya secara permanen memerlukan suatu proses dan sangat dipengaruhi oleh 


\section{PUBLICIANA : JURNAL ILMU SOSIAL DAN ILMU POLITIK \\ VOLUME 13 NO 2 \\ ISSN : $1979-0295$}

dimensi sosial, budaya, alam dan ilmu (H. Kodyat, 1983:4)

Ada yang mengatakan bahwa pariwisata adalah merupakan potensi/unggulan baru dalam mendongkrak peningkatan pendapatan masyarakat melalui tersedianya kesempatan kerja dan peluang kerja baru yang berpotensi untuk menggerakkan sektor-sektor ekonomi lain menjadi lebih antusias (Salah Wahab, 1975:55).

Sektor produktif dimaksud bisa berupa terkait industri-industri klasik seperti industri/perusahaan yang menghasilkan kerajinan tangan/makanan khas daerah yang bisa dijadikan oleh-oleh wisatawan yang melakukan perjalanan wisata, berkunjung dan mungkin bermalam di obyek wisata tersebut.

Obyek Wisata adalah daerah yang memiliki pesona baik alam/buatan mampu menyedot wisatawan untuk menikmati flora, fauna serta lingkungan alam dilakukan dengan cara individu / rombongan / group / kelompok. Kesemuanya berharap memperoleh kepuasan \& sama-sama menikmati hasil dengan melibatkan masyarakat sekitar kawasan wisata dan membuat/memodifikasi obyek-obyek baru sebagai destinasi wisata.

Komitmen dari semua elemen masyarakat perlu dilakukan dengan mengacu peraturan perundang-undangan tersebut mencakup pengelolaan sekaligus pengembangan kawasan alam menjadi pesona wisata yang dalam hal ini bisa berupa :

1. Ciptaan Tuhan Yang Maha Esa, berupa bumi, langit dan kekayaan alam didalamnya seperti flora tropis serta binatang-binatang langka semata untuk kepentingan manusia.

2. Hasil budidaya \& modifikasi manusia terhadap alam dimaksudkan untuk memenuhi tuntutan hidup dan kebutuhan dalam hal wisata yang terkait dengan pertanian, budaya, sejarah, agro dll maupun tempat-tempat hiburan lainnya.

3. Destinasi wisata prospektif lainnya yang barangkali perlu dikembangkan seiring dengan wisata alam, seperti : penginapan, climbing mountain, kuliner, arum jeram dll.

Kemudian dinyatakan juga bahwa objek wisata merupakan kawasan atau daerah bisa juga lingkungan alam dengan karakteristik tertentu selanjutnya dikelola ataupun dimodifikasi agar bisa berkembang dan lebih menarik sehingga wisatawan penasaran untuk mengunjunginya. (SK Merparpostel No. KM 98 PW 102 MPPT).

Pengembangan kawasan wisata pada dasarnya merupakan suatu kegiatan yang sangat panjang dan mungkin berkembang bahkan mungkin dapat menyentuh tataran norma-norma yang ada dalam masyarakat lokal sekitar kawasan wisata yang tentunya menuntut adanya langkahlangkah adaptasi, pemantauan, pengawasan dalam rangka memberika feed-back dari perencanaa yang telah dilakukan.

Terkait dengan upaya pengembangan Wisata Alam Kandung tidaklah cukup hanya dilakukan satu fihak tertentu saja, karena perlu pendanaan yang besar untuk perbaikan maupun 
penambahan wahana, misalnya untuk perbaikan kolam renang membutuhkan dana sekitar Rp. 30juta, kemudian belum lama ini diadakan penambahan untuk wahana fly fox sejauh 100 meter yang diperkirakan butuh dana minimal Rp. 80 juta, kemudian juga punya rencana/target untuk melakukan pengecoran jalan dari arah pintu masuk sampai menuju ke kawasan air terjun Gerojogan Sewu dengan estimasi biaya sekitar Rp. 500 juta. (Hasil wawancara, Pengelola Wisata Alam Kandung).

Kemudian menyangkut kelestarian alam di kawasan Wisata alam kandung hal ini dapat diilustrasikan dengan kegiatan warga sekitar yang bersimpuh salaing berhadapan dengan puluhan ambengan makanan/takir, kemudian ada tumpeng berukuran cukup besar berisi aneka makanan dan hasil bumi diletakan menunggu dipurak warga/diperebutkan.

Kegiatan ini dilakukan warga untuk menyambung tradisi sekaligus untuk membangun kesadaran warga dan pengunjung untuk mencintai dan melestarikan Alam Kandung agar tetap rimbun dan memberi sumber (air) kehidupan sepanjang masa (Hasil wawancara, Tokoh masyarakat).

Kemudian wisatawan (domistik / nasional / mancanegara) menginginkan akan terbebas dari kemungkinan terjadinya segala bencana di kawasan yang terletak di sekitar kawasana hutan lindung yang berada di perbatasan Tulungagung bagian tenggara dengan wilayah Kabupaten Blitar. Masyarakat mempunyai kepercayaan bahwa sumber air terjun Kandung merupakan cikal bakal kelestarian dan kemakmuran penduduk dan masyarakat sekitar sekitar kawasan wisata (lokal).

\section{METODOLOGI PENELITIAN}

Metode penelitian yang digunakan pada penelitian adalah metode penelitian kualitatif. Dengan begitu bermaksut mengemukakan realita sosial yang ada di obyek penelitian yang ditekankan dari sisi arti dan proses dengan menggambarkan kejadian-kejadian dalam masyarakat secara apa adanya.

Selanjutnya penelitian Deskriptif menekankan dan berupaya mengungkap/melukiskan realita sosial, fakta-fakta sosial yang dijadikan fokus penelitian dalam beberapa variabel dengan tidak melakukan komparasi serta melihat korelasinya dengan variabel yang lain. (Sugiyono 2009:11). Hal tersebut dapat dimaknai bahwa peneliti dimudahkan dalam mencari data yang obyektif untuk dapat mengungkap serta lebih faham tentang Wisata Alam dan Kelestarian Alam, Suatu upaya pengembangan kawasan pariwisata lokal berwawasan lingkungan. Penelitian ini dilakukan di Wisata Alam Kandung suatu kawasan di Desa Tanen Kecamatan Rejotangan Kabupaten Tulungagung.

Pendekatan yang dipakai penelitiadalah dengan memberikan gambaran sebatas upaya pengungkapan permasalahan, kondisi, event tanpa ditambah-tambahi (proses-seleksi) \&secara riil menyangkut gambaran selintas pandang di kawasan Wisata Alam Kandung dengan apa 
adanya.

Analisa dalam penelitian ini dilakukan dengan menggunakan analisa kualitatif yang didasarkan dari pertimbangan obyektif, serta untuk mendeskripsikan Wisata Alam dan Kelestarian Alam, suatu upaya pengembangan kawasan pariwisata lokal berwawasan lingkungan.

Sumber Informasi dipilih dari mereka yang diyakini mengetahui dan yang bersangkutan merupakan aktor-aktor terkait pengembangan Wisata Alam Kandung dan upaya pengembangan kawasan tersebut dengan tetapa menjaga kelestarian lingkungan alam. Informan dimaksud harus banyak ide-ide kreatf terkait kepariwisataan, aturan / norma, etika / perilaku, hal-hal \& tahapan yang menjadikan kawasan tersebut menjadi obyek wisata.

Para Sumber Informasi terpilih yakni :

1. Pengelola Wisata Alam Kandung

2. Tokoh masyarakat

3. Paguyuban Wisata Alam Kandung

4. Masyarakat sekitar kawasan wisata

5. Pengunjung

Adapun perolehan sumber data penelitian didapat dari :

1. Data Primer : Hal didapat dari masyarakat/pengunjung kawasan Wisata Alam Kandung

2. DataSekunder : Diperoleh dengan cara membaca buku-buku, akses internet, jurnal, serta aturan- aturan yang berkaitan.

Teknik mendapatkan data yang dilakukan dalam penelitian ini adalah:

1. Intervieuw

Dilakukan dengan tanya-jawab kepada sumber informasi yang telah dipilih seputar obyek penelitian. (Siswanto, 2011:58) Intervieuw yang dilakukan peneliti dimaksutkan untuk menggali informasi dan beberapa faktor yang berkaitan secara langsung maupun tidak langsung dengan Wisata Alam Kandung dan Kelestarian Lingkungan Alam. Dalam melakukan intervieuw digunakan pedoman/panduan atau apa saja yang mau ditanyakan kepada sumber informasi.

2. Observasi

Penelitian dengan pengamatan langsung tentang Wisata Alam Kandung yang berada di salah satu Desa kawasan Kecamatan Rejotangan wilayah Kabupaten Tulungagung yakni Desa Tanen serta upaya pengembangan pariwisata di kawasan tersebut.

3. Studi Kepustakaan

Dalam penelitian ini dilakukan sebagai upaya mendapatkan bahan/informasi melalui telaah teori yang ada di perpustakaan, dalam rangka menemukan telaahan ilmiah yang berkaitan dengan pokok bahasan. Telaah teoritis dapat bersumber pada hasil penulisan / penelitian, berkas-berkas yang terkait pokok bahasan. 
4. Dokumentasi

Dalam penelitian ini dilakukan dan dipergunakan guna mendapatkan data yang terkait dengan penelitian.

Setelah memperoleh bahan informasi dari obyek penelitian data tersebut kemudian ditata, ditampilkan, dianalisa secara kualitatif serta memberikan gambaran secara apa adanya sekaligus meberikan suatu pemaparan beberapa narasi yang ada di lapangan.

Untuk mempermudah dan memperjelas pemahaman terhadap konsep, teori terkait pokok bahasan yang ditelaah. Selanjutnya yang akan dijadikan Fokus Penelitian adalah Wisata Alam Kandung dan Kelestarian Alam, upaya pengembangan kawasan pariwisata lokal yang berwawasan lingkungan, di Desa Tanen Kecamatan Rejotangan Kabupaten Tulungagung.

\section{HASIL DAN PEMBAHASAN}

Seiring dengan perkembangan dunia wisata dewasa ini, Tulungagung semakin getol untuk menggenjot perpariwisataan dengan menggali destinasi wisata yang berada di wilayahnya tidak mau kalah dengan Kota/Kabupaten lain yang telah melakukan hal yang sama.

Tulungagung yang juga terkenal dengan sebutan penghasil marmer ini mengembangkan berbagai masakan khas asli daerah/lokal, kesenian, bisnis-retail, wisata alam, pantai, pariwisataagro, dll.

Sebagaimana diketahui bersama dewasa ini menekuni usaha di bidang kepariwisataan lagi marak-maraknya dan digandrungi di seantero dunia/global.

Dari beberapa destinasi wisata yang ada di kawasan Kabupaten Tulungagung, satu diantaranya berpotensi jika dilakukan pengembangan di masa depan yang prospetif yakni wisata alam.

Dari beberapa wisata alam selain pantai, masih ada pesona keindahan alam lainnya yang tidak dapat dibohongi keelokannya yang bersinggungan dengan air yakni air terjun. Salah satu dari pesona air terjun jangan sampai terlewatkan yakni adalah air terjun Sendang Sewu yang berada di kawasan Air Mancur Sendang Sewu Wisata Alam Kandung. Merupakan salah satu daerah dari banyak destinasi wisata (wisata alam) yang memang cukup lama dikenal di kalangan masyarakat Tulungagung.

Air terjun Grojogan Sewu memiliki potensi dan terkenal merupakan salah satu andalan dalam Wisata Alam Kandung yang berada di Desa Tanen, Kecamatan Rejotangan, Kabupaten Tulungagung-Jawa Timur ini memiliki luas sekitar 4,7 hektar, suatu kawasan yang sangat potensial untuk dikembangkan.

Pemilihan Wisata di kawasan Kandung adalah sangat tepat karena ada beberapa pilihan obyek wisata \& permaian / atraksi yang ditampilkan / disuguhkan di kawasan tersebut. banyak hal yang dapat dinikmati di kawasan ini. Di kawasan tersebut jangan sampai kelewatan juga dimanfaatkan sebagai obyek dokumentasi dengan latar belakang air terjun. 
Air terjun Grojogan Sewunya Wisata Kandung ini relatif tidak terlalu deras, tapi keadaan air terjunnya cukup untuk dipakai menyegarkan bagi wisatawan. Namun demikian bagi wisatawan / pengunjung yang hobi berenang tidak dianjurkan berenang di bawah air terjun disebabkan sangat curam sampai 10 meter, dan kadang ada pusaran air dimana seringkali mamakan / mengakibatkan pengunjung nakal (tidak mematuhi anjuran) jadi korban.

Sebagai penggantinya disana ada sebuah kolam yang tidak terlalu besar di bagian bagian barat grojogan sewu sebagai tempat untuk bermain pengunjung. Sebagian kawasan wisata Kandung yang ada cukup pemandangan menjadikan pengunjung betah dan kerasan bersantaisantai sambil menelusuri panorama alam yang natural yang indah serta luas, mulai pintu gapura selamat datang dengan membeli karcis tanda masuk Rp.5.000/orang.

Setelah parkir pengunjung, sudah banyak ditemukan lapak-lapak dengan pajangan berbagai jenis jajanan \& minuman dengan kemasan yang bermacam-macam, banyak pepohonan ada yang besar dan kecil dapat mempercantik dipakai sebagai background dan untuk atribut dalam berfoto foto ria.

Sesampainya di spot air terjun yang menjadikan takjub pengunjung dengan keindahan panorama alam dari mahakarya sang Pencipta. Selain itu kawasan ini begitu indah dengan spot/tempat pengambilan gambar dengan nuansa hutan panorama gemericiknya grojogan sewu yang jatuh menerpa bebatuan disebuah kolam/telaga kecil, menghiasinya dan menjadikan suasana di kawasan itu alami serta menjadikan pengujung tidak puas kalau manghabiskan waktu hanya 1-2 jam saja.

Lokasi kawasan Wisata Alam Kandung lumayan meriah untuk dikunjungi tidak saja didorong pesona kecantikan alamnya, tetapi juga seringkali ada hiburan hiburan pada hari-hari / even-even tertentu semakin menambah semarak kawasan tersebut.

Menurut Edi Wibowo selaku pengelola wisata alam Kandung mengatakan bahwa pengembangan dan pengelolaan wisata alam di Kandung belum optimal ditengarai minimnya dana yang dipakai untuk pengelolaan. Selanjutnya ditegaskan sebenarnya dari hasil penjualan tiket masuk kawasan wisata sudah disepakati yakni : 10\% untuk LMDH (Lembaga Masyarakat Desa Hutan) Kandung Makmur, 60\% untuk Paguyuban Kandung Sejahtera dan 30\% untuk KPH Blitar (kawasan hutan kandung ini dibawah Kesatuan Pemangkuan Hutan Blitar).

Berdasarkan paparan diatas pengembangan Wisata Alam Kandung berpulang kepada kemauan fihak yang telah bersepakat tersebut serta fihak fihak terkait lainnya. Sebenarnya jika dibandingkan dengan sebelum masa / era otonomi daerah, pengelolaan Wisata Alam Kandung sudah memberikan profit untuk pengelolanya juga telah memberikan kontribusi kepada warga lokal yang berdekatana dengan kawasan wisata.

Langsung maupun tidak langsung peningkatan pengelolaan kawasan Wisata Alam Kandung telah membuka beberapa bisnis baru \& kesempatan kerja barudisekitar kawasan 
Kandung. Kawasan Kandung akan menarik perhatian dan itu terbukti dengan dibangunnya beberapa sarana prasarana penunjang terkoneksinya dengan kawasan wisata.

Namun demikian yang perlu tetap dipegang teguh bahwa pengembangan Wisata Alam Kandung jangan mengakibatkan rusak keaslian dan indahnya kawasan Wisata Alam Kandung itu sendiri. Upaya untuk memperindah suasana \& panorama alam tidak harus merubah secara frontal sehingga menghilangkan ciri khas daerah / masyarakat lokal.

\section{Gambar wisata Alam Kandung}
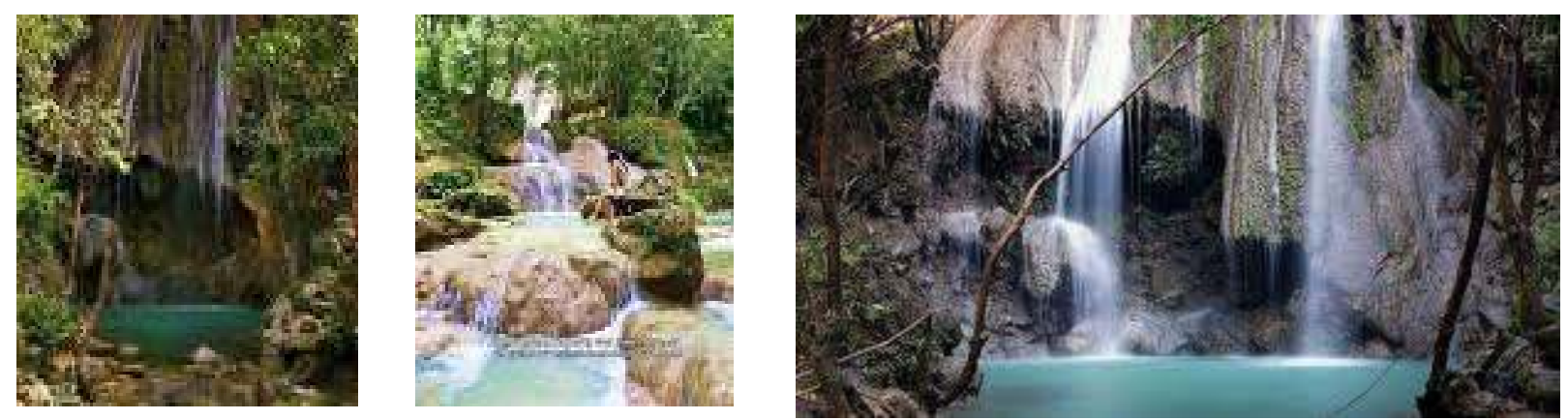

\section{TAHAPAN PENELITIAN}

\begin{tabular}{|c|c|c|c|c|c|c|c|c|c|c|c|c|}
\hline \multirow[t]{2}{*}{ Jenis Kegiatan } & \multicolumn{12}{|c|}{ Bulan } \\
\hline & 1 & 2 & 3 & 4 & 5 & 6 & 7 & 8 & 9 & 10 & 11 & 12 \\
\hline Studi pustaka dan Pendahuluan & & & & & & & & & & & & \\
\hline Pembuatan Instrumen & & & & & & & & & & & & \\
\hline Penilaian Subyek Penelitian & & & & & & & & & & & & \\
\hline Pengumpulan Data & & & & & & & & & & & & \\
\hline Analisa Data & & & & & & & & & & & & \\
\hline Penyusunan Draft Laporan & & & & & & & & & & & & \\
\hline Pelaporan & & & & & & & & & & & & \\
\hline
\end{tabular}

\section{KESIMPULAN}

Di wilayah Kabupaten Tulungagung kawasan Wisata Alam Kandung terletak pada bagian wilayah Tenggara dan berbatasan dengan wilayah Kabupaten Blitar, dengan karakteristik pegunungan, hutan tropis, terdapat air terjun, ada danau kecil dengan kedalaman air berkisar 4 - 5 meter.

Pengembangan Wisata alam Kandung memerlukan kerjasama antara swasta, masyarakat lokal dan tentunya dukungan penuh dari pemerintah daerah untuk mengoptimalkan upaya pengembangan potensi wisata tetap lestari dan terjaga keseimbangan alam di kawasan tersebut. 
Pengelolaan Wisata Alam Kandung telah membawa perkembangan ekonomi masyarakat lokal ditandai dengan munculnya berbagai usaha kecil sebagai multiplier effect di kawasan wisata yang pada akirnya dapat meningkatkan kesejahteraan masyarakat sekitar kususnya dan peningkatan pendapatan asli daerah Kabupaten Tulungagung pada umumnya.

\section{REKOMENDASI}

Bagi Pemerintah Kabupaten Tulungagung dalam hal ini Dinas yang terkait, untuk lebih giat berupaya mengembangkan wisata alam yang ada termasuk Wisata Alam Kandung dengan keberpihakan pemerintah secara ekonomi, politik, hukum maupun sosial budaya.

Bagi Swasta yang berkecimpung dalam pengelolaan Wisata Alam Kandung tidak hanya mengejar dan berorientasi bisnis melulu tetapi tetap komitmen demi perkembangan dan kemajuan Wisata Alam Kandung di masa-masa mendatang.

Bagi masyarakat hendaknya tetap memperhatikan kelestarian lingkungan alam dengan selalu menjaga kebersihan kawasan wisata, tidak berperilaku yang tidak ramah lingkungan seperti corat-coret/vandalisme, eksploitasi/perambahan hutan diluar batas kewajaran dll.

\section{DAFTAR PUSTAKA}

Chafid Fandeli, 1997, Dasar-dasar Manajemen Kepariwisataan Alam, Yogyakarta: Liberti.

Damanik, Janianton dan Helmut F. Weber. 2006. Perencanaan Ekowisata: Dari Teori ke Aplikasi. PUSPAR UGM dan Penerbit Andi. Yogyakarta.

David, F.R. 2004. Manajemen StrategisKonsep. Edisi ketujuh. PT. Prenhallindo, Jakarta.

Hadinoto, 1997. Perencanaan Pengembangan Destinasi Pariwisata, Jakarta: PT. Gramedia.

Hari Karyono, 1997. Kepariwisataan, Jakarta: Penerbit PT. Gramedia Widisauna Indonesia.

Kusmayadi, Sugiarto E, 2000. Metodologi Penelitian Dalam Bidang Kepariwisataan,

Jakarta: PT Gramedia Pustaka Utama.

Marpaung Happy, 2000. Pengetahuan Kepariwistaan, Bandung: Alfabeta.

Suyitno, 2001, Perencanaan Wisata, Yogyakarta : Kanisius Yogyakarta 